\title{
The violence of planning law and the production of risk in Lima
}

\author{
Rita Lambert \\ The Bartlett Development Planning Unit, University College London, United Kingdom
}

\section{A R T I C L E I N F O}

\section{Keywords:}

Urban planning

Informal urbanisation

Violence

Abstraction

Risk

Lima

\begin{abstract}
A B S T R A C T
Counteracting law violation and the haphazard occupation of marginal land as an explanation for how risk becomes inherent to informal urbanisation, I demonstrate in this paper that hazardous conditions are an outcome of practices that seek to comply with planning law. Risk on the steep slopes of Lima is reproduced by unchanged and inflexible planning regulations and instruments, and not by their absence. Building on scholarship at the nexus of planning and informality, and borrowing from socio-spatial and legal geography, I argue that planning law and legal texts regulate the spatial layouts of human settlements in ways that produce concrete abstraction and exacerbate unintended outcomes.

Using extensive case study research and ethnographic methods, I unpack three perverse spatial configurations on the peripheral slopes of Lima: the grid layout resulting in excessively steep access ways, electricity poles in the middle of staircases and dangerous evacuation routes. I demonstrate how manoeuvres of fragmentation, homogenisation, and hierarchical ordering, active in planning processes and legal texts, lead to material and corporeal violence that maintain dwellers in perpetual landscapes of risk.
\end{abstract}

\section{Introduction}

How did an electricity pole make it to the middle of the staircase? I came across this curious sight while walking through a settlement on the peripheral slopes of Lima. I watched a woman carrying a heavy water container on her shoulder, unsteadily circumventing the pole, while another held her child tightly by the hand leading him around it. In the neighbouring settlement further up the slope, I encountered another pole together with a streetlight in a similar position (Fig. 1). These two obstructed the width of the staircase. Unable to see the logic in what to me was a perverse outcome of spatial planning, I was even more perplexed by how such outcomes could be repeated in different settlements. When I asked the nearby kiosk attendant, he was unable to explain although he had been present when the electrification system was being installed. He said the workers had to break the staircase, and neighbours subsequently got together to buy sand and concrete to repair the damage.

Spatial outcomes that increment risk for inhabitants take many different forms in the newer settlements of Lima. Amongst them are the unapologetic gridded street layouts rubber-stamped on every slope, giving rise to excessively steep access ways. Also common are evacuation routes that lead to dead ends, which are particularly alarming considering Lima is located in a seismic zone. In theory, these spatial configurations could have been avoided. They are however widespread, producing material and corporeal violence ${ }^{1}$ as they shape inhabitants' everyday lives in taxing ways.

Since settlements on the peripheral slopes of Lima emerge and consolidate through inhabitants' own efforts, the responsibility for such outcomes is often attributed to dwellers. The authorities and academics I interviewed highlight people's 'defiance of planning regulations, their haphazard occupation of land, as well as their lack of knowledge, technical knowhow and inability to plan the territory'. These reductionist explanations are unhelpful for understanding why these undesired outcomes are continuously produced. In many ways, these explanations align with wider literature that positions informal urbanisation as an externality of planning or as an exclusionary outcome of

E-mail address: rita.lambert@ucl.ac.uk.

URL: https://iris.ucl.ac.uk/iris/browse/profile?upi=RCLAM63.

${ }^{1}$ Violence is a complex concept. For the purpose of this paper, violence is the exercise of unwanted physical force, whether actual or implied (Platt, 1992). Violence is not exceptional but quotidian. It is not only a product of power but also its vector (Blomley, 2008). 


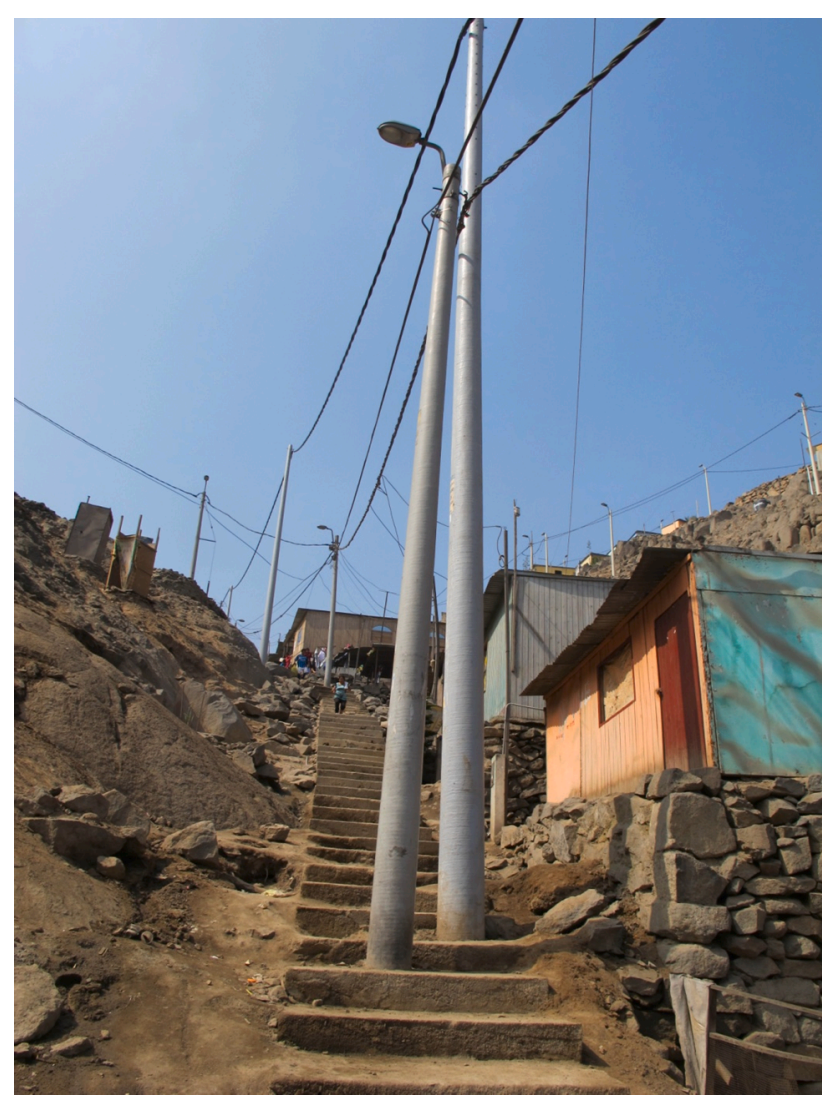

Fig. 1. Two electricity poles in the middle of a staircase in the higher parts of San Juan de Lurigancho, Lima. Photo (C) author (2015).

planning. The tangential treatment of planning also means that its link to risk $^{2}$ remains unexplored.

Poverty and risk intersect in major ways (Pelling, 2003). In the global South, these manifest in human settlements that concentrate vulnerable populations. Narratives on informal urbanisation mainly highlight economic, demographic, and geographic factors to explain the unequal landscape of risk (Zeiderman, 2012). Excluded by economic and political forces, the urban poor evidently access land and housing markets on hazard-prone marginal land such as steep slopes, flood plains, valleys, marshy areas and watercourses (Davis, 2006; Hardoy et al., 2001). The risk they are exposed to is, therefore, predominantly attributed to the precarious character of the land, but also to the violation of planning laws. Many scholars highlight the departure from onerous building codes, leading to poor planning and quality of housing that contribute to risk. Accurate as these explanations may be, they naturalise the exposure to hazards, making risk an inevitable condition of informal urbanisation.

\footnotetext{
${ }^{2}$ Risk is commonly defined as the interplay between hazards, vulnerability and capacity to act; the probability of negative consequences or losses induced by a combination or complicity of natural or man-made threats together with conditions of vulnerability (UNISDR, 2009; Wisner et al., 2004) are counterbalanced by the capacity or resilience to face and adapt.
}

Moving beyond an emphasis on the marginal nature of land or the marginality of planning per se in processes of auto-construction, I argue for a critical examination of the interaction between planning law and informal urbanisation. In this paper, I explore the performative aspects of planning processes, regulations, and instruments. By analysing the practice of planning law and its structuring effects in human settlements, I expose how it relates to unintended outcomes and the production of risk $^{3}$.

The case of Lima is pertinent because of the unequivocal centrality of planning regulations and instruments in the formation of its human settlements. The latter develop through reversed urbanism and autoconstruction in a slow and incremental manner. Inhabitants follow planning regulations and municipal processes from the moment they occupy the land as this shapes their entitlements to basic services and their expectations on securing tenure. Moreover, technicians and civil engineers, within and outside government institutions are routinely involved, as are technical tools such as settlement layout plans (planos de lotizacion). Despite this engagement with planning regulations, instruments, and professionals, the resultant spatial configurations trap inhabitants in cycles of everyday risk. This risk manifests as threats or dangers such as rock falls, building collapse, and occurrence of disease, and account for the most severe impacts on the lives, livelihoods, and assets of the urban poor (see work done under the action-research project cLima sin Riesgo ${ }^{4}$ and Peruvian NGO CENCA ${ }^{5}$ ).

Building upon the emerging planning and informality scholarship, and drawing from socio-spatial and legal geography literature, I aim to better understand how planning law links to the physicality of the urban in its material ontology of informal settlements, as well as the operation of law within such materiality. I here seek to contribute to literature on informality/illegality and the limited scholarship on the connection between law and space. Following Blomley, 2008, I contend that the mundane and routine ways in which laws are often "enforced" demand the most careful inquiry. I interrogate how law is practiced through legal texts and how their translation on the ground produce taxing outcomes for inhabitants. I demonstrate how planning instruments, based on representational abstraction, lead to 'concrete abstraction' that in turn gives rise to symbolic, material and corporeal violence.

The paper is structured into four parts. I first offer a discussion on the relationship between planning and informal urbanisation. To engage with how planning and risk are related, I revert to scholarship on abstraction and violence. Second, I outline the methods used and the informants consulted in the research. Third, I elaborate on the concrete outcomes I mentioned at the beginning of this paper: the grid layout, the staircases and the evacuation routes. I organise the findings to cover three mechanisms of abstraction- fragmentation, homogenisation, and

\footnotetext{
${ }^{3}$ Different conceptualisations of risk and extensive literature on urban risk governance frame risk as a socially constructed process (cf. Oliver-Smith et al. 2016; Lavell 2012; Pelling 2012; Rebotier, 2012; Wisner et al. 2004). Several authors help us to think about how risk comes to inhabit landscapes of poverty rather than the other way around (cf. Zeiderman 2012). Focusing on the discursive/constructivist conceptualisation of risk, they frame risk as a governmental strategy to justify eviction, relocation or the withholding of public investments in informal settlements. For this paper, I focus on a limited aspect of risk as an outcome, thus emphasising an essentialist/realist conceptualisation of risk.

${ }^{4}$ cLimaSinRiesgo is a two-year action-research project funded in 2015 by CDKN and led by the Bartlett Development Planning Unit-UCL, in collaboration with CENCA and CIDAP, that analysed risk traps in Metropolitan Lima's poorer areas and sought to develop strategies to disrupt risk. See http://www.climasinriesgo.net for the project website.

${ }^{5}$ CENCA is an organization that works for pro-poor development in San Juan de Lurigancho and is part of a movement that contributes to developing emancipatory processes through co-production of knowledge, territorial management and the right to housing and habitat. See https://www.cenca.org.
} pe/en/ for the institutional website. 
hierarchical ordering. I end the paper by reflecting on why planning law and legal texts become black-boxed, and how the difficulty of deciphering the role they play leads to the maintenance of human settlements in perpetual informality and within landscapes of risk.

\section{The relationship between planning law and informal urbanisation}

Much scholarship highlights the failure of planning as being ineffective in addressing the needs of the urban poor, and in some regions, for being directly involved in worsening poverty, inequality and the environment (Watson, 2009). Although not always entirely spontaneous and unplanned, as a form of incremental urbanism that occurs from the ground up, human settlements are often defined through their lack of compliance with the norms that govern urban development (Connolly and Wigle 2017). As such, they are believed to operate outside of laws regulating space (Duhau \& Cruz, 2006) and even as defiant vis-à-vis planning for infringing such laws (see Azuela, 1989; Connolly, 2009; De Soto, 1989). From such perspectives, informality is an effect of onerous planning regulations that offer no alternatives but for the urban poor to violate them in order to dwell in the city (De Soto, 1989; Kironde, 2006; Payne and Majale, 2004). Various debates focus on the violations of the rule of law, stressing these as forms of resistance, subversion, politics of the subalterns against their marginalisation, or as creative responses in overregulated environments (see Benjamin, 2004; Chatterjee, 2004; De Soto, 1989, 2001; Scott, 1985).

Scholars working at the nexus of informality/legality have advanced the debate in this regard. Counteracting the emphasis on the failure of planning, those centring on inequality and conflicts in cities of the global South argue that negative impacts of planning regulations on the urban poor are not just a result of wrongly appropriated, misunderstood or inefficient planning systems, but in many cases, are due to corrupt manipulation or the use of the system for political domination and control (see for example De Satge and Watson 2018). From this postcolonial standpoint, the focus is not so much on the planning system itself, but rather on the appropriation and abuse of the planning system by elites to secure their interests.

Of particular weight, due to the number of academic contributions, is the hegemony of states in their use of planning (see Yiftachel 1998 for a detailed discussion on the dark side of planning). Urban informality and marginality are seen to be discursive strategies, contingently defined and constructed by national governments to justify their actions (Galland \& Elinbaum, 2018). Roy (2009), for example, contends that the Indian state preserves a large number of urban dwellers in spaces which are deemed illegal/informal in order to secure calculated flexibility to act on these settlements and decide what will thrive and what will not. Similarly, Bhan (2016) asserts that practices of planning in India, framed in the 'public interest', determine which settlements will be eradicated. From a Latin American perspective, the ambiguous and transactional role of state-led planning and regulation are active in governing informality (Azuela \& Meneses-Reyes, 2014; Muller \& Segura, 2017; Wigle, 2014). State actions framed as a pro-poor approach, such as regularisation and land titling of informal settlements, have also been critiqued as a form of domination, through clientelist co-option that maintain social inequalities (see for example Ramírez Corzo \& Riofrío 2005; Varley 1998; Driant 1991). Connolly and Wigle (2017) explore the role that everyday land use planning practices play in governing informal settlements and regularisation processes, arguing that plans, regulations and practices contribute to the re-construction of informality, inasmuch as these are directly linked to the discursive and material enactments of regularisation by government agencies.

Socio-legal scholars add to these debates by demonstrating how everyday urban life is governed by laws and regulations (Valverde, 2009) and how these are not absent but central for dwellers in human settlements. Das (2004, p. 226) argues that "struggles for legitimacy for those living on the borders of law/illegality, cannot now be fully realised through active resistance or political organisation, but through explicit engagements with formal and legal processes". Van Gelder (2010) shows how the normative informal orders of 'squatters' are incapable of replacing all the vital functions of the state. He highlights how squatters find themselves subordinated to and subsumed within the regulatory frameworks of 'formal' and legal mechanisms in the city. In the same line, Datta (2012) contends that there is a misrecognition of the actual effect and impact that law and legal geographies have on the lives of the urban poor due to the violence inherent in property relations.

Acknowledging these important contributions, there are broadly two different approaches. On the one hand, human settlements are understood as 'overflows' or externalities of planning law; that is, no intentionality is necessarily seen to be at play. On the other, the emphasis is placed on such settlements as outcomes of the purposeful adoption of the planning system towards exclusionary ends. Legal scholarship clearly adds value to these debates by drawing attention to the practice and structuring effect of law itself.

\subsection{Planning practice and the translation of law and legal texts}

As laws need to be practiced, a discrepancy exists between law as text and law as action (Blomley, 2014; Valverde, 2012). The written law requires translation, which opens room for interpretation, negotiation and manoeuvre. Tensions are created through the practice of everyday regulation as legal texts "are applied, enforced, twisted, and blurred in everyday life" (Haid \& Hilbrandt, 2019, p. 559). Moreover, laws are embedded in governance since a range of actors are involved in their application and they are not always systematically followed. Inhabitants who build their own homes, as well as developers, try to comply with city ordinances and regulations but usually do so unevenly (Caldeira, 2017). The conditions of irregularity regarding land tenure and construction vary widely (see Bhan 2016; Holston 2008; Payne \& DurandLasserve 2012). As Holston (1991a) has shown, each phase involves a great amount of improvisation - a bricolage of complex strategies and calculations that often result in unforeseen outcomes. Recognising that actors do not operate in fully regulated environments and can deviate from or interpret laws in their own ways, I contend that an emphasis on bricolage within practices of law translation are insufficient to explain spatial outcomes that are consistently repeated - as opposed to being one-offs - as seen in Lima. An unexplored link between planning laws, practices and undesired outcomes still persists, which cannot be reduced to the violation of law or its partial application. Planning law is inscribed within logics for governing 'at a distance', to control and dominate. It is however also embedded in governance and depends on various actors. Because planning law produces material effects that escape the intentionality of social actors, we are forced to pay attention to its performative aspect and how it relates to violence.

\subsection{The violence of law}

Law and violence are somewhat antithetical. Law is supposed to promote justice and regulate violence, not produce it. Blomley (2008) argues that there is a tendency to treat violence as exclusively discursive which can hide the physicality of law, including its material and corporeal violences (Cheah \& Grosz, 1996). The challenge is to think through the ways in which violence entails both practice and representations, while also keeping a critical geographic imaginary. Certain strands of extra-legal theory, and the interdisciplinary field of law and geography studies, reflect the emergence of new orientations towards questions of space, relationality, and the material (Butler, 2016). Much has been made of Foucault's (2004) notions of governmentality and biopolitics. Moreover, law and geography, as violent processes, have been studied by various scholars (Blomley, 2014; Laceda, 2018; Loftus, 2015), and so have the violence of abstraction (Lefebvre, 1991; Marx, 1973; Sayer, 1987), and abstraction as a real concrete process (Osborne, 2004; Toscano, 2008). 
Central to Lefebvre's (1991) work on the production of space is a recognition of the role played by spatialised modes of abstraction, such as law and the intervention of state power in fragmenting, homogenising and hierarchically ordering abstract space, thereby generating its characteristics forms of violence and domination. Through its commitment to the generality of legal rules and the equality of legal subjects, law both reproduces spatial hierarchies and operates as a force for the homogenisation of socio-spatial relations. Moreover, the real and discursive violence of law plays a crucial role in processes of spatial fragmentation. In this way, legalisation and regulating instruments draw through space, prohibiting or permitting particular spatial uses and enforcing such divisions in practice (Lefebvre, 1991). Lefebvre's concept of 'concrete abstraction' allows us to understand law as an abstraction which becomes spatially grounded through its ordering and control of material bodies, their practices and the relations between them (Loftus, 2015). Borrowing from this scholarship, I regard outcomes that exacerbate risk for inhabitants in Lima as manifestations of concrete abstraction, out of place and dismissive of place, and traceable to planning laws and legal texts.

\section{Research methodology}

I undertook the research that informed this paper between 2013 and 2018 in the newly established human settlement at the periphery of Lima, in the district of San Juan de Lurigancho. The district is one of the most populous in Lima with over 1 million inhabitants, and it has an unprecedented urbanisation rate on high-risk areas with steep terrain. During the 5-year research, I first sought to understand the various stages of settlement formation and consolidation and their connection with planning practices and processes. I used a combination of mobile methods including transect walks, interviews on the move with settlement leaders and inhabitants, shadowing of technicians and engineers at work, as well as following the circulation and use of legal texts in the form of settlement layout plans. I also relied on spatial analysis to interrogate the spatial configuration of settlements. I conducted 45 indepth open and semi-structured interviews with individuals (officials and technicians) from 17 national and local government institutions, 6 with service providers, 13 with specific independent individuals (e.g. water and sanitation engineers, civil engineers, risk estimation engineers and road engineers). I also undertook in-depth interviews with community leaders in 20 settlements, and at least 5 inhabitants (men and women) from each settlement. In sum, I conducted 246 in-depth open and semi-structured interviews. I also shadowed civil engineers commissioned by settlement leaders in the establishment of 5 settlements. This involved following the engineers over the course of full days while they produced layout plans, worked in offices, and oversaw the demarcation of plots in the field before inhabitants could occupy the land. I supplemented this shadowing and participant observation with in-depth interviews so informants could explain what exactly they were doing and why.

In addition, I analysed the practices and the spatial information that related to key spatial outcomes that I considered problematic for inhabitants.

\section{Fragmentation, homogenisation, and hierarchical ordering in Lima's human settlements}

The precarious occupation of steep slopes at the edge of the city of Lima has emerged and grown particularly in the last 25 years, during a period of 'seismic silence' with no major earth movements since 1974 (Laos, 2016). The typical settlements that form on the hillsides currently extend over a vast area of the city. In 2016, it was estimated that $30 \%$ of Lima's 9.7 million people lived on slopes deemed 'high-risk' by city authorities (Laos, 2016). Inhabitants face daily health risks stemming from the lack of basic services, which can take many years to obtain. They also live with difficult access due to the steep terrain, the risk of

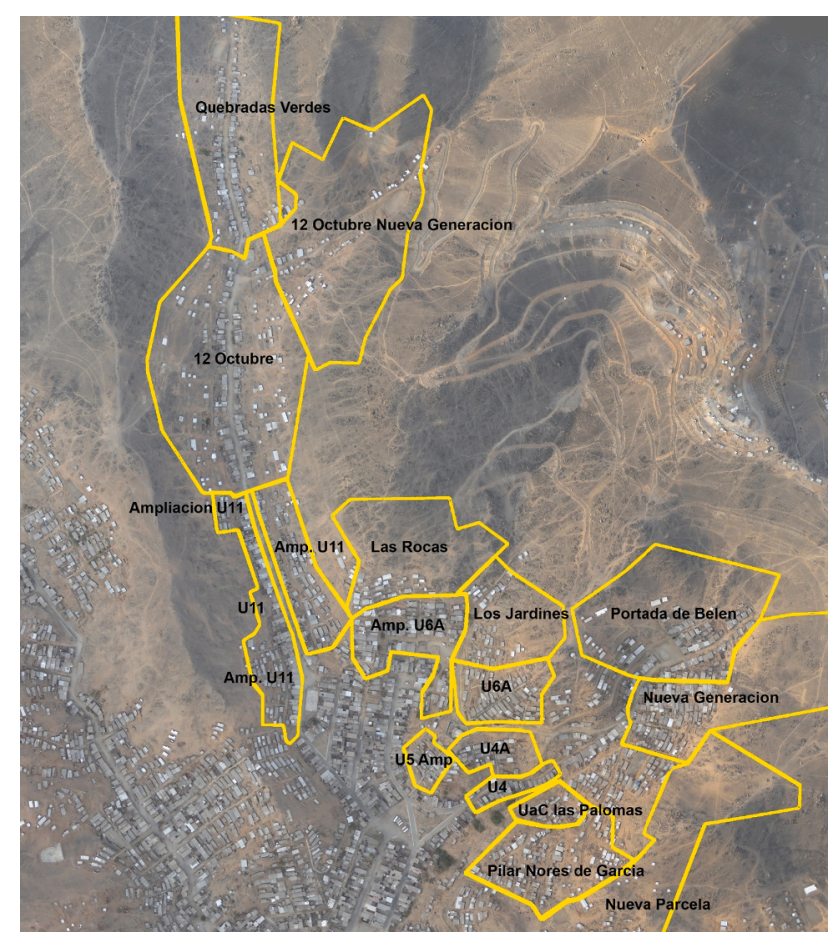

Fig. 2. Aerial image of various settlements and their boundaries (in yellow) in the higher parts of José Carlos Mariátegui. Source: author (2014). (For interpretation of the references to colour in this figure legend, the reader is referred to the web version of this article.)

building collapse linked to precarious construction, and the danger of rock falls from the continuous opening of new roads and the occupation of areas further upslope (Lambert and Poblet, 2015). Inhabitants living in these areas have to incur considerable investments (time, labour and resources) to mitigate risk (Allen et al., 2017).

People access land by buying a plot from organised groups, which can either be established settlers, or so-called 'pirate subdividers' or 'land traffickers'. These groups operate through the usurpation of government and peasant community land, subdividing areas and selling to those seeking a place to live (Lambert, 2021). In the process of land occupation, inhabitants organise through community organisations or Agrupaciones familiares (AF), which de facto govern all collective affairs in the neighbourhood and interface with governmental institutions and programmes. The AFs are usually left to their own devices and have to initiate all processes to ameliorate the living conditions within settlements.

A slope is typically divided into different settlements with clearly demarcated perimeters, each containing between 20 and 300 households. Each settlement has its own AF and operates in an insular manner focusing on development within its boundaries. The resultant landscape is a series of individual and uniquely named settlements (Fig. 2), working in an introverted fashion within their borders. From the initial stages of land occupation and throughout, settlement leaders engage with planning instruments, professionals and regulations, which is atypical compared to the majority of accounts from other contexts.

In the existing literature on informal urbanisation, the interaction between inhabitants of human settlements and the planning apparatus of the state is seen to occur at specific and intermittent stages, namely when certain rights are demanded by dwellers such as the acquisition of services and formalisation of tenure. In the case of 'squatter settlements' in Buenos Aires for example, Van Gelder (2010) notes two distinct and conflicting stages. In the first stage of occupation, settlers violate or work outside regulatory frameworks to control land, and are met with repression and threats by state actors. In the second stage, having become conversant in the state's laws and policies, settlers navigate and 


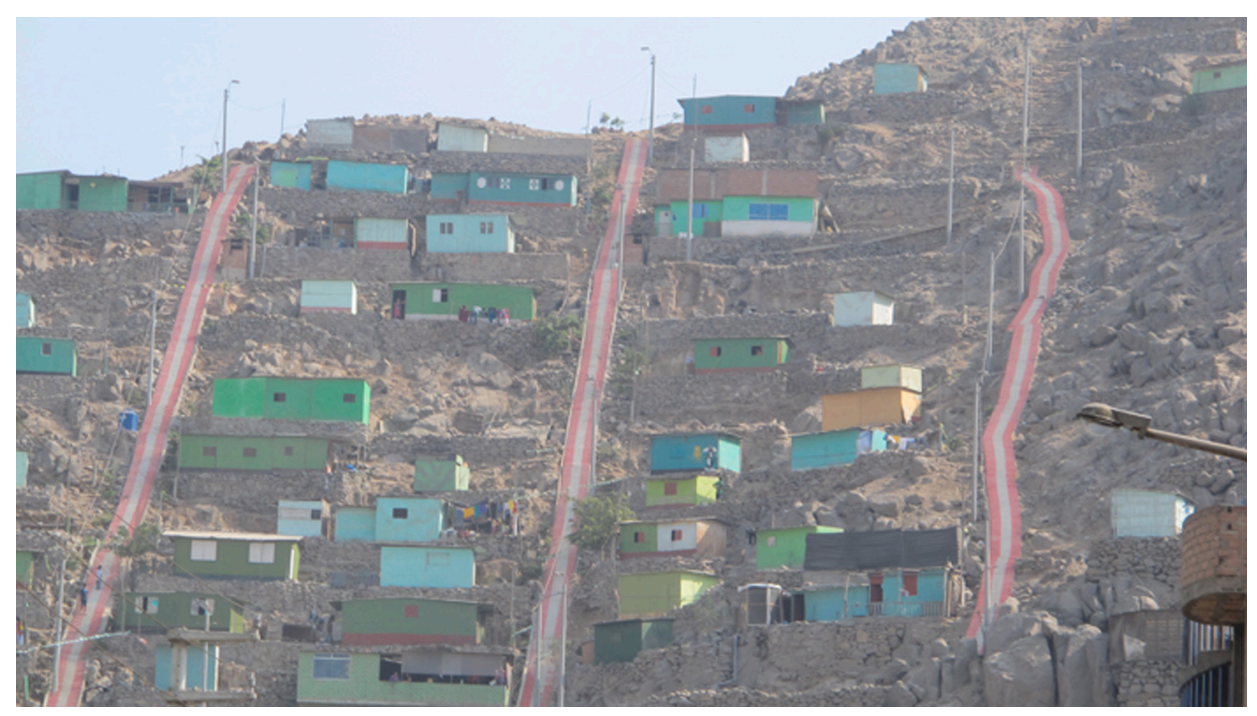

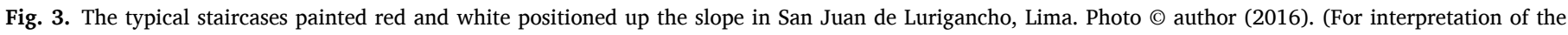
references to colour in this figure legend, the reader is referred to the web version of this article.)

adapt to the planning system to meet the requirements it poses for legalisation. As such, Van Gelder argues that inhabitants' strategies shift from resistance and noncompliance in the early phases of development, to adaptation and adjustment in subsequent stages. Similarly Caldeira (2017, p. 7), drawing on various cases in the global South, also highlights that the state is present in numerous ways but frequently acts "after the fact to modify spaces that are already built and inhabited".

In the case of Lima, however, each progressive stage is effectively linked to the regulatory framework, which determines a number of entitlements. To achieve recognition, inhabitants need to show that the plot sizes and streets pattern follow urban norms. To ensure that their settlement develops in line with planning standards, and to avoid difficulties once they enter the different administrative processes, settlement leaders commission certified engineers to draw a settlement layout plan compliant with the planning norms. The layout plan is then directly transferred onto the ground using chalk, guiding the division of plots and the general spatial occupation of the slope. Similarly, before settlements can apply for water and electricity, they need to demonstrate that they have mitigated risk on the slope through the construction of retention walls and concrete staircases. Only then the district municipality will certify their layout plan, which allows them to subsequently apply for basic services from service providers.

Thus, spatial outcomes that comply with planning standards are not an end point but are hurdles to be overcome at different moments in the acquisition of entitlements. From the onset, regulatory frameworks structure the underlying field in which different actors operate and with which they must negotiate to arrive at their desired goals. The law is 'performed' by inhabitants and speculators alike because it allows them to progress. But the main question here is how does it lead to unwanted spatial outcomes such as excessively steep staircases, misplaced electricity poles and dangerous evacuation routes?

\subsection{The grid and steep staircases}

One of the most striking sights when observing the urbanisation of the periphery in Lima is the way the grid, as a spatial layout, takes a hierarchical position and is rubber-stamped on the steepest of slopes. Despite the possibility of occupying the terrain in ways that allow gentler and safer access ways, the grid is positioned against the topography, leading to steep staircases without landings (see Fig. 3). These staircases, negotiated by inhabitants on a daily basis, increase the risk of falls and make the everyday tasks of carrying heavy loads up the slope more challenging, whether this be water for the day, a child in the belly, building materials or daily necessities. Moreover, the adoption of a gridded layout on such steep terrain requires relatively high investments from inhabitants to level the plots and build adequate retention walls.

Many explanations have been offered for why the slopes are occupied with a grid as the main structuring device. Some see it as an essentialist response, with inhabitants drawing from their Andean inheritance to replicate the building techniques and inhabit steep terrain (interview with urban planner/academic, October 2014). Others see the adoption of the grid as a response to an internal desire of settlers to belong to the city. Since the grid is at the heart of the 'formal city', its replication is understood as a claim to citizenship (Golda-Pongratz, 2009). Interviewees have also added to these explanations, dismissing inhabitants by highlighting "their lack of imagination to do things differently, compounded by the limited technical and design knowledge they possess" (interview with official at Ministry of Housing, April 2016).

Through a historical tracing, I was able to establish how and why the grid came to be adopted as a standard layout in human settlements and its long-standing connection to planning norms. I identified a particular moment in time when the grid was imposed, never evolving, regardless of the topography. Comparing earlier settlements of the 1940s and 1950 s to those formed after the 1980s, a noticeable difference is apparent in the way the slope is occupied. Despite similar topographic conditions, earlier settlements present gentler access ways, working with the slope morphology and without a regular pattern. From the 1960s onwards, the grid layout, which exemplified 'good' planning principles, was enforced on human settlements with the emergence of the 1961 Law of Barriadas № 13517.

Prior to this law, the state took different stances towards human settlements or so called barriadas, including repression, tolerance, concession of rights, and finally recognition (Collier, 1976). With the realisation that incremental urbanism was not the problem but in fact the solution to meet housing demand, compounded with mounting political pressure from discontented marginalised inhabitants, the planning system evolved by engaging with barriadas (De Soto, 1989; Mosqueira, 2000; Eyzaguirre, 1998). And in 1961, it formally acknowledged these with the Law of Barriadas and integrated them into the planning system.

With the law, a dedicated municipal process named Saneamiento Fisico y Legal was devised. It enabled the physical and legal formalisation of existing settlements. As stipulated in the law, the first process consisted of authorities identifying the settlements that needed to be regularised (De Soto, 1989; Riofrio, 1991). An effort was therefore made to discern, classify and catalogue existing barriadas. In parallel, technical 


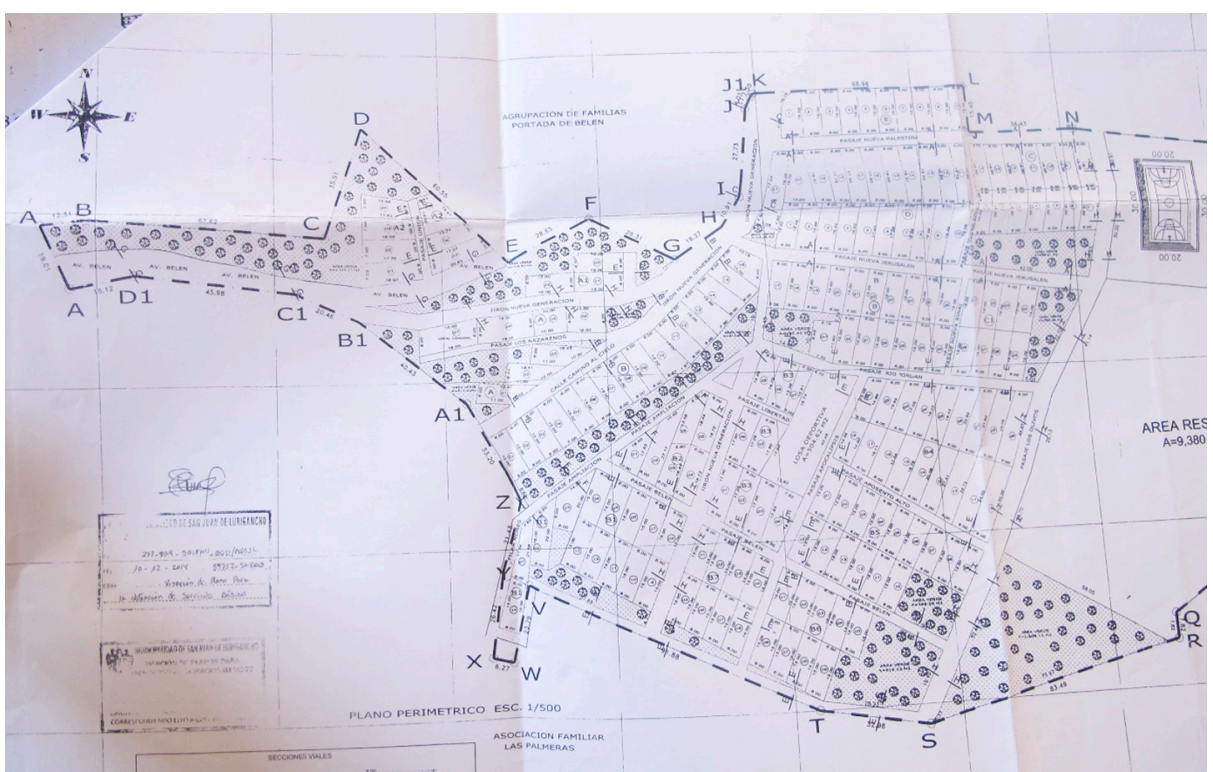

Fig. 4. Example of a settlement layout plan showing the perimeter as a dotted line and the division of plots within it. Photo $\odot$ author (2016).

layout plans would be drawn by state technicians (mainly architects and engineers), in line with urban norms and planning regulations for the width of roads, size of plots, buffer zones, and open spaces amongst others. The settlement layout plans produced were meant as guides to reshape existing settlements so they could reflect the proposed layout plan. In many settlements, this meant realigning the already occupied plots and shifting people within the boundaries of demarcated plots following the layout plan. After this process, legal regularisation would follow, first involving the transferral of land ownership to the Peruvian state, and subsequently the legal ownership of the individual plots to qualifying inhabitants.

With the passing of law № 13517 , a substantial number of lawyers, architects, engineers and technicians infiltrated the administration.
They took a determinant role setting base rules for settlements' spatial layout using layout plans that could be tied to land titles. A change in representation and practice took hold and the gridding of space was adopted as the most efficient and rational layout. Through these processes, the government operated as the bearer of abstract space, forcing barriadas to take up the grid, while ignoring the pre-existing conditions. The mediation of abstract space thus operated by denying the content of local space, dominating it regardless of its previous social content. The layout plans played an important role. They facilitated a two-step abstraction: the representation of the ground onto paper and subsequently the re-projection of the paper onto the ground. Thus, the abstraction on paper came to define the shape the space eventually took. In this way, symbolic and material violations went hand in hand.

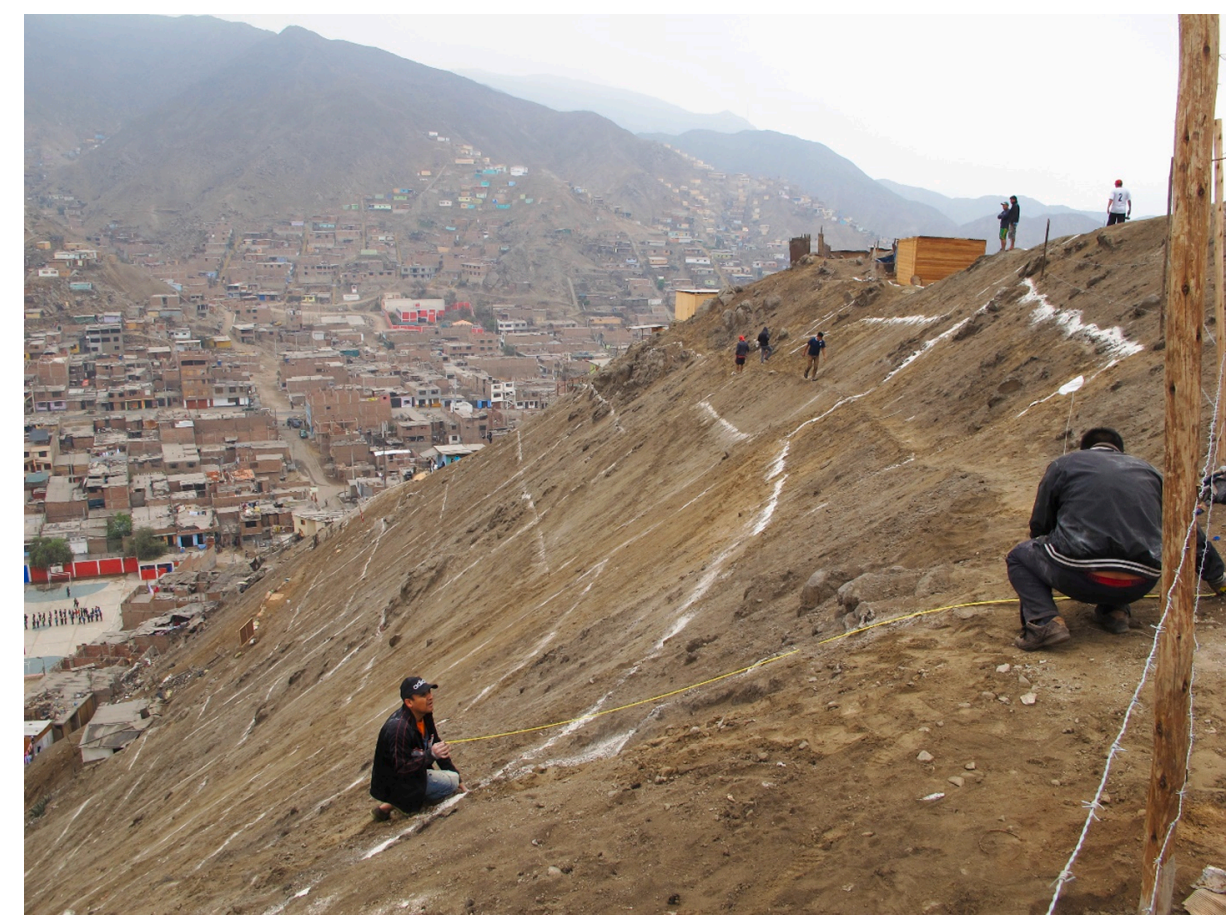

Fig. 5. The emergence of a new settlement: using chalk and guided by the layout plan, an organised group transfers the grid on a slope in San Juan de Lurigancho. Photo $($ ) author (2016). 


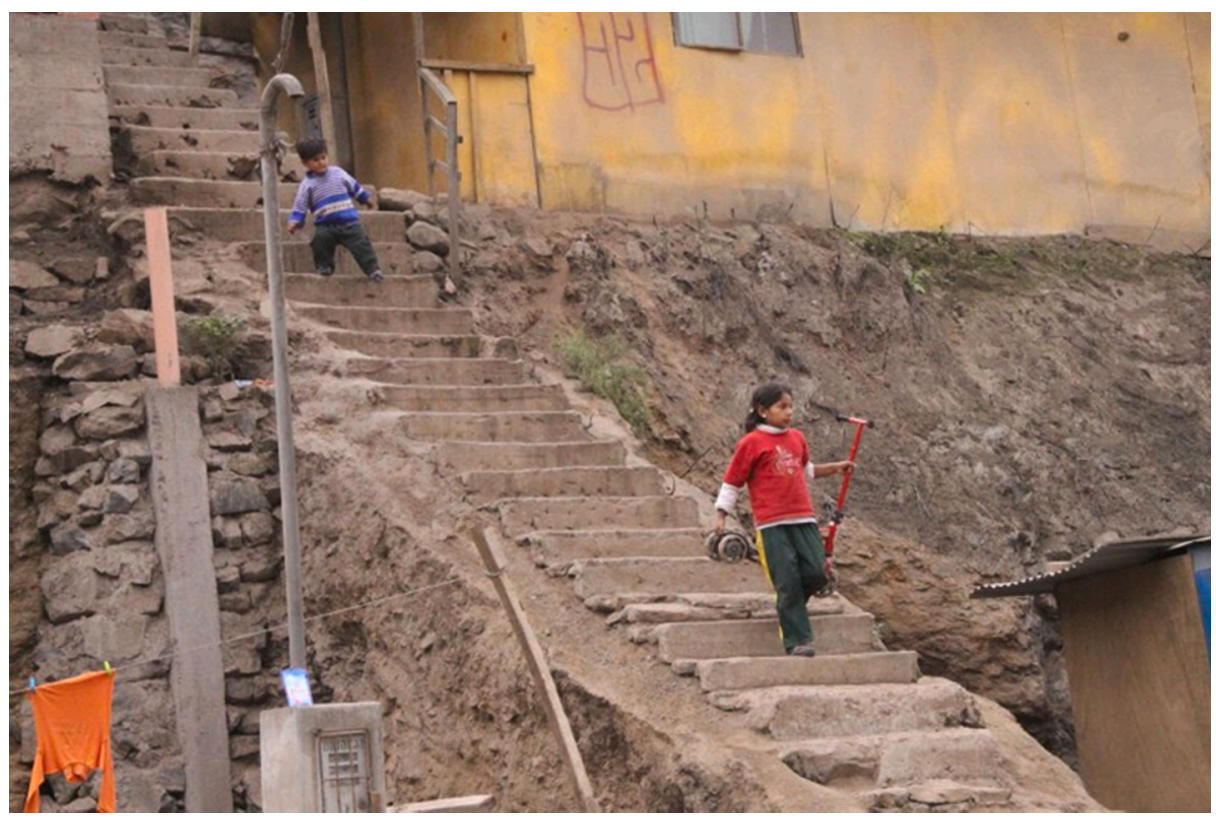

Fig. 6. The hazardous steep stairs that inhabitants have to negotiate on a daily basis. Photo JustoMedio.

Over time, these violations were normalised and even internalised within the practices of inhabitants. As the state could not keep up with the process of Saneamiento Fisico Legal, settlers took over parts of the process to speed up their recognition and regularisation. To leapfrog the remodelling stage that older barriadas had to go through before titling, inhabitants occupied land in a gridded fashion in line with urban planning norms. They commissioned engineers that would produce layout plans to guide a compliant occupation of land. Thus, from the 1960s, families "invaded with the plan" (Ramirez \& Riofrio, 2006, p. 12). Whether the occupation of land was state- or people-led, the 'newer' settlements took an entirely gridded layout. From the 1980s onwards, as adequate land in Lima was exhausted, urbanisation began on the steep peripheral slopes of the city. However, planning regulations and cartographic conventions did not adapt. Moreover, inhabitants, as well as technicians, sought to follow them without making changes. This meant that the grid was unapologetically stamped onto the slopes without adaptation.

A close examination of the practices of land occupation in the present day exposes the hierarchical position of the abstract grid. Before dwellers take over a parcel of land, a civil engineer, commissioned by an $\mathrm{AF}$, draws a layout plan that will guide the parcelling of land (Fig. 4).

Both the AFs and the civil engineers are driven to maximise the number of plots within settlement boundaries. For AFs, the funds needed for improving communal areas are secured through the sale of plots; for civil engineers, their commission is tied to the number of plots they are able to draw within the perimeter of a settlement. To begin with, using a total station in the field, engineers locate the coordinates of the bounded area to be occupied. Back at their office, they input the perimeter in a computer and use an automatic function in AutoCAD to grid the area. The gridding function is generic; it is locked to the standards of plot and street dimensions and is also set to maximise plots by producing back-toback rows of plots. Contour lines are absent from the otherwise black space of the AutoCAD file, and little thought is given to the adoption of a more sympathetic layout that could minimise steep access ways. As an engineer explains: "as long as we show one road from the new settlement uphill joining another road further down to allow access, then the rest can be staircases. I must only comply with the dimensions of plots and streets to ensure enough clearance. Otherwise, I am free to position these how I see fit" (interview with civil engineer, October 2014).

The computer and its black space annihilate context, structuring the final layout of the settlement and contribute to access ways and evacuation routes that are difficult to negotiate. The omission of contour lines on layout plans, as well as the adoption of the grid, are not decisions solely in the hands of civil engineers. They conform with the cartographic standards and planning norms expected by the district municipality in the recognition and certification stages. Abstraction is thus inscribed in the very standards rather than being the result of oversight.

On the ground, a group of men transfer the layout plan directly onto the ground using chalk (Fig. 5). The straight lines of the grid are laid unapologetically, at times cutting through large boulders on the way. In theory, if the chalk lines were to circumvent obstacles, the layout could still comply with the planning norms; yet as one interviewee notes:

"It is like this because we have always done it so. If we start to think about avoiding this or that rock, it will take more time and brain power to make everything line up and we would be losing plots. We might also end up with an irregular layout which could alert the municipality's attention and would delay our paperwork because of extra checks" (interview with community leader, May 2016).

The grid translates into a terraced occupation with limited vehicular access and steep stairs that increase the risk of falls and injuries (Fig. 6). It has disciplinary power and regulates social relations. Women are especially affected as they bear the disproportionate burden of productive and reproductive roles. The rigidity of the grid used on the slopes demonstrates the violence of planning devices that remain unchanged. It sediments a concrete abstraction that contributes to perpetual corporeal violence because it stabilises risk for inhabitants.

\subsection{The electricity pole in the middle of the staircase}

As I have demonstrated, homogenisation - as the annihilation of difference - is operational before the occupation of land, but also throughout the different stages of development. Once the physical layout has been fixed, inhabitants consolidate their settlement and mitigate risk through the building of retention walls and concrete staircases. Once this stage is complete, they can apply for certification of their layout plan from the district municipality, which in turn enables them to apply for water and electricity from service providers.

In the case of electricity, settlement leaders submit the certified 


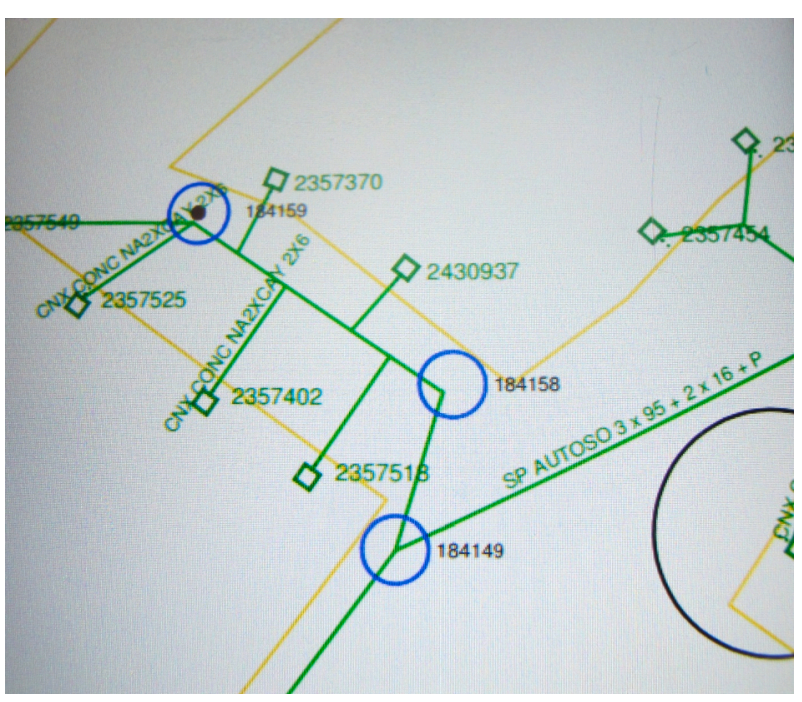

Fig. 7. EDELNOR's digital file showing the blocks of the settlement in yellow and the electrical system in green with minimal reference to other context. Photo () author (2015). (For interpretation of the references to colour in this figure legend, the reader is referred to the web version of this article.)

layout plan together with other documents to the electricity provider EDELNOR. The provider subsequently sends the plan to a subcontractor to be digitised in AutoCAD. A technician takes on the design of the electrification project and calculates the number of posts, cables, type, and level of lighting required. The appointed technician first goes to the field and checks for inhabitation using the certified plan as well as the dimensions of access ways and plots. To be economically viable, $60 \%$ of the plots must be occupied and 20-40 plots are the minimum number considered before an electrification project goes ahead.

The technician fills in an Excel sheet noting the number of plots, the material of the housing, and details of the settlement. They also use the plan to check whether the sections of the roads correspond to the drawing. If different, they take note of the changes required as one technician explains:

"I examine everything on the ground with the installation in mind. I consider how workers carrying electricity poles will circulate. I tell inhabitants to improve the staircases if these are still rough or rocky, so workers can easily go all the way up to place the electricity posts" (interview with technicians from SATEP, October 2015).

After the first visit, the technician sends the file to EDELNOR, who in turn forwards it to the client with the observations to be corrected. This process usually takes many visits as settlements find it difficult to make all the changes (interview with settlement leader, October 2015). Once these have been addressed and checked by the technician, the design is approved and inhabitants pay for individual electricity meters.

The EDELNOR AutoCAD file primarily shows the infrastructure, such as meters and transformers, as well as the connections between these. Technicians represented the base minimum from the context; they focus on the electrification system in isolation and overlook how it might touch the ground or integrate with other systems such as water pipes (Fig. 7).

The layout plan facilitates a conceptual emptying of space. Territorially and conceptually, it separates a bounded space from the things and relations that inform it. The space is imagined as purely abstract with meaning only in terms of the logic of plot delimitation and electrification.

The execution of the works is undertaken by yet another subcontracted company. Changes can occur in the process of construction, diverging from the design, especially when a clear clash occurs on the ground between electricity poles and the location of water pipes.
Although there is a negotiation between these systems, and workers take decisions to avoid clashes during construction, the inflexibility and hierarchical position of the layout plans is evident. As an inhabitant explains:

"They [the workers] came to install the poles and placed them in the middle of the stairs. Why not at the edge? There was no clearance space, although we could have organised ourselves to make space. As neighbours, we spoke out but at the end we chose not to argue. It is hard enough we have been without electricity for 5 years, we did not want to stall the works. So, they broke our staircase and placed the light poles. We then had to fix our stairs to make them good again (interview with inhabitant October 2015).

The trade-offs made are materialised on the ground as obstructed evacuation routes. Since socially negotiated outcomes are not an option, abortive work and resources are incured by vulnerable inhabitants. Despite the many field visits of engineers, the lack of coordination between systems and the de-territorialised nature of the design, produce effects that stabilise conditions of risk.

\subsection{Unsafe evacuation routes}

The state's planning laws and legal texts foment social, as much as spatial fragmentation. Settlements have their own leaders, sets of rules, and priorities. Moreover, all AFs are encouraged to submit their own layout plans and work in an insular manner through all stages from recognition, certification for basic services and land titling. Although each new settlement that emerges joins on to the one below through a primary access route extended by inhabitants, the various AFs organise within their own settlement boundaries, working towards their respective plans. Each settlement advances at its own pace independent from those adjacent to it. This results in heterogeneous conditions on the slopes characterised by different levels of precariousness in terms of infrastructure, services, and building structures, as well as tenure security and property rights.

This promotes a disjointed landscape. In most cases, secondary routes within settlements come to a halt at the boundary and those of adjacent settlements take a different layout. I traced how decisions are made about the location of evacuation routes and the checks carried out by the Civil Defence Department within the district municipality. Clearly, the possibilities imagined are confined within the settlement's perimeter. The prevalent logic in the location of escape route signage works on the basis that inhabitants must escape through their own secondary routes before joining the primary route. The capacity building workshops for emergency preparedness conducted by the Civil Defence Department also reinforce the autonomy of each settlement. The risk officer explains:

"Inhabitants have control over their own settlement but not that of others. Also, adjacent settlements might not be as consolidated, so they cannot depend on those access routes. We at the municipality make them follow the requirements to plan within their own settlement's perimeter because inhabitants will also organise in this way" (interview with risk estimator, May 2016).

In practice, however, this logic can lead to unsafe conditions. When entering the titling stage, there are important steps for risk management and mitigation at the district municipality level, as well as at the higher level of the Metropolitan Municipality of Lima. Again at this stage, the AFs hire technicians with knowledge of the process to produce the compulsory documents, which include the contingency, signalisation, and evacuation plans. They decide the emergency strategy of settlements on the basis of the layout plan, devoid of context beyond the settlement boundaries. There is no indication of the steepness of the terrain, nor the existence of obstacles. The various signs for emergency exit, fire extinguishers and safe areas are marked onto the plan. The 


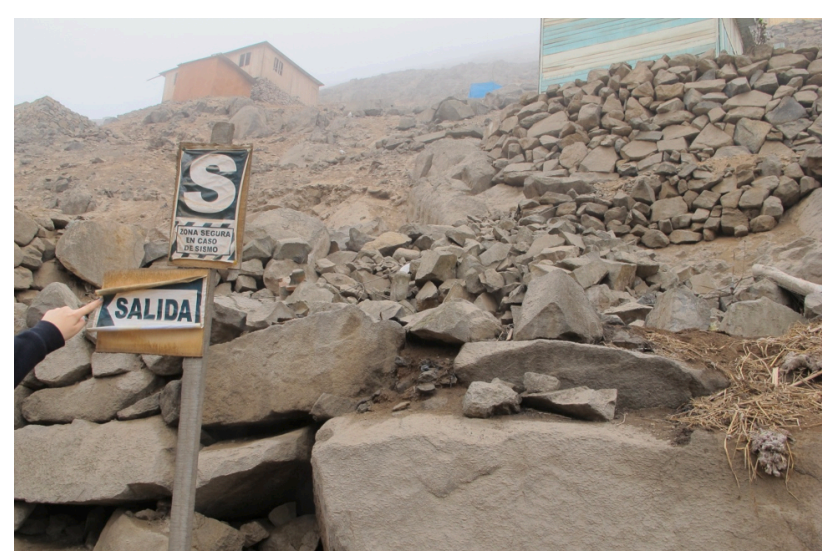

Fig. 8. Evacuation route under a loose retention wall and large rocks. Photo $(\subset$ author (2016).

latter is convincing and gives coherence to a strategy, which is questionable in reality. The evacuation routes may be dangerous and even impossible to negotiate should an earthquake or mudslide occur. For example, exit signs are placed under potentially unstable retention walls or paths leading to dangerous cliff-like conditions (Fig. 8). This way of working forecloses more appropriate solutions that consider a broader scale and an evacuation strategy that encompasses more than one settlement at a time. It further instils the disconnect between settlements and exacerbates risk.

Fragmentation is concrete and tangible on the slopes. The disjointed landscape is not only the result of settlers' introverted approach; it is also promoted by planning processes that demand a fragmented conceptualisation of the slope. The planning law furthermore upholds layout plans that not only hide possible problems but actively promote them.

Examining the practices and legal texts that translate planning laws into compliant spatial configurations, it becomes evident how abstraction operates through fragmentation, homogenisation and hierarchical ordering. These subsequently create concrete material conditions that encapsulate these very manoeuvres. In doing so, inhabitants are subjected to corporeal violence as they have no choice but to live with risk. At the same time, risk - product of the abstraction and violence inherent in planning laws and processes - is internalised and black boxed, escaping interrogation.

\section{Conclusion}

Contributing to existing literature at the nexus of planning and informal urbanisation, I have demonstrated the need to critically examine the performative role of planning law, legal texts and planning processes in producing symbolic, material and corporeal violence. In Lima's human settlements, the violence linked to geographic space is key to understand how landscapes of risk and poverty correlate and are perpetuated in time.

The main manoeuvres- homogenisation, hierarchical ordering, and fragmentation- inherent in the translation of planning laws onto the ground, instil an abstraction that is tangibly concrete. This, in turn, determines an unjust development trajectory for settlements which concentrate vulnerable populations. The settlement layout plans, as legal texts and instruments for this translation, play a crucial role. They operate through a series of abstractions that transform representation on paper into literal marks on the ground without any contextual considerations. In doing so, they actively foment hazardous conditions.

I have shown in this paper how undesired outcomes emerge as Lima's low-income inhabitants seek to comply with planning regulations. Risk is, therefore, not necessarily created through dwellers deviant practices but through compliance with urban norms deemed 'standard' and 'good practice' by the governmental institutions, and upheld by inhabitants, technicians, and authorities alike. Here, risk in an outcome of the unchanged planning law and legal texts and not a sign of their absence.

Because the link between planning and the production of undesired outcomes is seldom a focus of examination, it becomes difficult to explain how such outcomes can be continuously reproduced. Identifying the social and material aspects that contribute to the production of risk becomes challenging, which in turn makes it difficult to conceivesafer urbanisation pathways. Planning law is heavily invested in uncoupling itself from violence, rendering it invisible and impersonal. An ethnographic approach to analyse mundane processes and legal texts has potential to observe planning in practice and capture its violence.

As governments in the global South increasingly turn to a risk lens to manage cities and their populations, recognising the central role of planning law in informal urbanisation and the connection to risk is a first step towards meaningful reform. This also reaffirms the role that planners and policy makers can play to rethink the planning apparatus of the state and carve more sustainable and just urban development pathways.

\section{Acknowledgment}

This research was supported by the Economic and Social Research Council (ESRC grant no. 1327267).

\section{References}

Allen, A., Zilbert Soto, L., Wesely, J., Belkow, T., Ferro, V., Lambert, R., Langdown, I., Samanamú, A., 2017. From state agencies to ordinary citizens: reframing riskmitigation investments and their impact to disrupt urban risk traps in Lima, Peru. Environment and Urbanization 29 (2), 477-502. https://doi.org/10.1177/ 0956247817706061.

Azuela, A., 1989. La ciudad, la propiedad privada y el derecho. El Colegio de México. Azuela, A., Meneses-Reyes, R., 2014. The everyday formation of the urban space: Law and Poverty in Mexico City. In: Braverman, I., Blomley, N., Delaney, D., Kedar, A (Eds.), The Expanding Spaces of Law: A Timely Legal Geography. Stanford University Press, pp. 167-190.

Benjamin, S., 2004. Urban land transformation for pro-poor economies. Geoforum 35 (2), 177-187. https://doi.org/10.1016/j.geoforum.2003.08.004.

Bhan, G., 2016. In the public's interest: evictions, citizenship and inequality in contemporary Delhi. Orient BlackSwan.

Blomley, N., 2008. Law, property, and the geography of violence: The frontier, the survey, and the grid. Annals of the Association of American Geographers 93 (1), $121-141$.

Blomley, N., 2014. Making space for property. Annals of the Association of American Geographers 104 (6), 1291-1306. https://doi.org/10.1080/ 00045608.2014.941738.

Butler, C., 2016. Abstraction beyond a ' law of thought ': on space, appropriation and concrete abstraction. Law Critique 27 (3), 247-268. https://doi.org/10.1007/ s10978-016-9186-z.

Caldeira, T., 2017. Peripheral urbanization: autoconstruction, transversal logics, and politics in cities of the global south. Environment Planning D: Society and Space 35 (1), 3-20. https://doi.org/10.1177/0263775816658479.

Chatterjee, P., 2004. The politics of the governed: reflections on popular politics in most of the world. Columbia University Press.

Cheah, P., Grosz, E., 1996. The body of the law: notes towards a theory of corporeal justice. In: Cheah, P., Fraser, D., Grbich, J. (Eds.), Thinking through the body of law. New York University Press, pp. 3-25.

Collier, D., 1976. Squatters and oligarchs: authoritarian rule and policy change in Peru. The Johns Hopkins University Press.

Connolly, P., 2009. Observing the evolution of irregular settlements: Mexico City's 'colonias populares', 1990 to 2005. International Development Planning Review 31 (1), 1-35. https://doi.org/10.3828/idpr.31.1.2.

Connolly, P., Wigle, J., 2017. (Re)constructing informality and "doing regularization" in the conservation zone of Mexico city. Planning Theory \& Practice 18 (2), 183-201. https://doi.org/10.1080/14649357.2017.1279678.

Das, V., 2004. The signature of the State: the paradox of illegibility. In: Das, V., Poole, D. (Eds.), Anthropology in the Margins of the State. James Currey, pp. 225-252.

Datta, A., 2012. The illegal city: space, law and gender in a Delhi squatter settlement. The illegal city: space, law and gender in a Delhi squatter settlement. Ashgate Publishing Limited.

Davis, M., 2006. Planet of Slums. Planet of slums. Verso.

De Satge, R., Watson, V., 2018. Urban planning in the global South. Palgrave Macmillan.

De Soto, H., 1989. The other path: the economic answer to terrorism. Basic Books.

Driant, J.-C., 1991. Las barriadas de Lima- Historia e interpretacion. DESCO.

Duhau, E., Cruz, M.S., 2006. El suelo, la vivienda, los instrumentos de ordenación territorial y los programas urbanos. In R. Coulomb \& M. Schteingart (Eds.), Entre el estado y el mercado: La vivienda en el México de hoy (pp. 389-444). Miguel Angel Porrúa. 
Eyzaguirre, H., 1998. La violencia intencional de Lima Metropolitana: magnitud, impacto económico y evaluación de políticas de control, 1985-1995 (No. 332). Banco Interamericano de Desarrollo.

De Soto, H., 2001. The mystery of capital: why capitalism triumphs in the West and fails everywhere else. Black Swan.

Galland, D., Elinbaum, P., 2018. Positioning Latin America within the southern turn in planning: perspectives on an "emerging field". Disp- The Planning Review 54 (1), 48-54. https://doi.org/10.1080/02513625.2018.1454696.

Golda-Pongratz, K., 2009. La transformacion de estructura y significado del centro de Lima. Tres aproximaciones. In D. Manuel (Ed.), Peru: la construccion sociocultural del espacio territorial y sus centralidades (pp. 151-188). Olacchi.

Haid, C.G., Hilbrandt, H., 2019. Urban informality and the State: geographical translations and conceptual alliances. International Journal of Urban Regional Research 43 (3), 551-562. https://doi.org/10.1111/1468-2427.12700.

Hardoy, J., Mitlin, D., Satterthwaite, D., 2001. Environmental problems in an urbanizing world. Earthscan. https://doi.org/10.4324/9781315071732.

Holston, J., 1991a. Autoconstruction in working-class Brazil. Cultural Anthropol. 6, $447-465$.

Holston, J., 2008. Insurgent citizenship: disjunctions of democracy and modernity in Brazil. Princeton University Press.

Kironde, L., 2006. The regulatory framework, unplanned development and urban poverty: findings from Dar es Salaam, Tanzania. Land Use Policy 23 (4), 460-472. https://doi.org/10.1016/j.landusepol.2005.07.004.

Laceda, D., 2018. The 'Visible Hand' of the State: urbanization of favelas as a violent abstraction of space. In: Dale, K., Kingma, S., Wasserma, V. (Eds.), Organizational space and beyond. Routledge, pp. 283-306.

Lambert, R., Poblet, R., 2015. Mapping to reduce urban risk. [Digital scholarly resource]. Retrieved from: https://climasinriesgo.net/wp-content/uploads/2016/01/ENGLIS H Final-Policy-Brief2 v5 09Feb 2016 cLsR rp-1.pdf.

Lambert, R., 2021. Land trafficking and the fertile spaces of legality. International Journal of Urban and Regional Research 45 (1), 21-38. https://doi.org/10.1111/ 1468-2427.12975.

Laos, J.P., 2016. Vivir en las alturas. El Comercio 8-10. https://elcomercio.pe/eldominic al/actualidad/vivir-alturas-392960.

Lavell, A., 2012. Reflections: advancing development-based interpretations and interventions in disaster risk: some conceptual and contextual stumbling blocks. Environmental Hazards 11 (3), 242-246. https://doi.org/10.1080/ 17477891.2012 .698845 .

Lefebvre, H., 1991. The production of space. Blackwell.

Loftus, A., 2015. Violent geographical abstractions. Environment Planning D: Society and Space 33 (2), 366-381. https://doi.org/10.1068/d14120p.

Marx, K., 1973. Grundrisse: Foundations of the critique of political economy (rough draft). Penguin.

Mosqueira, E., 2000. Las reformas institucionales para la creación de un sistema de derechos de propiedad. In: Abusada, R., Du Bois, F., Morón, E., Valderrama, J. (Eds.), La reforma incompleta. Universidad del Pacífico-Instituto Peruano de Economía.

Muller, F., Segura, R., 2017. The uses of informality: urban development and social distinction in Mexico city. Latin Am. Perspect. 44 (214), 158-175. https://doi.org/ 10.1177/0094582X16682760.

Oliver-Smith, A., Alcántara-Ayala, I., Burton, I., Lavell, A., 2016. The social construction of disaster risk: seeking root causes. International Journal of Disaster Risk Reduction 22, 469-474. https://doi.org/10.1016/j.ijdrr.2016.10.006.

Osborne, P., 2004. The reproach of abstraction. Radical Philosophy 127, 21-28.
Payne, G., Durand-Lasserve, 2012. Holding on: security of tenure, types, policies, practices, and challenges. Paper prepared for the Special Rapporteur on Adequate Housing, UN.

Payne, G., Majale, M., 2004. The urban housing manual: making regulatory frameworks work for the poor. Earthscan Publications Limited.

Pelling, M. (Ed.)., 2003. Natural Disasters and Development in a Globalizing World. Routledge.

Pelling, M., 2012. The vulnerability of cities: natural disasters and social resilience. Routledge.

Platt, T., 1992. The concept of violence as descriptive and polemic. International Social Science Journal 2, 185-192.

Ramírez Corzo, D., Riofrío, G., 2005. Land titling: a path to urban inclusion? Policy and practice of the Peruvian model. Urban Observatory DESCO 1-13.

Ramirez, D., Riofrio, G., 2006. Formalización de la propiedad y mejoramiento de barrios: bien legal, bien marginal. Estudios urbanos, Investigaciones. DESCO.

Riofrio, G., 1991. Producir la ciudad (popular) de los '90- Entre el Mercado y el Estado. DESCO.

Rebotier, J., 2012. Vulnerability conditions and risk representations in Latin-America: framing the territorializing urban risk. Global Environmental Change 22 (2), 391-398. https://doi.org/10.1016/j.gloenvcha.2011.12.002.

Roy, A., 2009. Why India cannot plan its cities: informality, insurgence and the idiom of urbanization. Planning Theory 8 (1), 76-87. https://doi.org/10.1177/ 1473095208099299.

Sayer, D., 1987. The violence of abstraction. Blackwell.

Scott, J.C., 1985. Weapons of the weak: everyday forms of peasant resistance. Yale University Press.

Toscano, A., 2008. The culture of abstraction. Theory, Culture \& Society 25 (4), 57-75. https://doi.org/10.1177/0263276408091983.

UNISDR, 2009. UNISDR Terminology on Disaster Risk Reduction. Terminology on disaster risk reduction. United Nations.

Valverde, M., 2009. Laws of the street. City \& Society 21 (2), 163-181. https://doi.org/ 10.1111/j.1548-744X.2009.01020.x.

Valverde, M., 2012. Everyday law on the street: city governance in an age of diversity. The University of Chicago Press.

Van Gelder, J.L., 2010. Tales of deviance and control: on space, rules, and law in squatter settlements. Law \& Society Review 44 (2), 239-268. https://doi.org/10.1111/ j.1540-5893.2010.00406.x.

Varley, A., 1998. The political uses of illegality: evidence from urban Mexico. In: Fernandes, E., Varley, A. (Eds.), Illegal cities: law and urban change in developing countries. Zed Books, pp. 172-190.

Watson, V., 2009. The planned city sweeps the poor away: urban planning and 21st century urbanisation. Progress in Planning 72 (3), 151-193. https://doi.org/ 10.1016/j.progress.2009.06.002.

Wigle, J., 2014. The "graying" of "green" zones: Spatial governance and irregular settlement in Xochimilco, Mexico City. International Journal of Urban and Regional Ressearch 38 (2), 573-589. https://doi.org/10.1111/1468-2427.12019.

Wisner, B., Blaikie, P., Cannon, T., Davis, I., 2004. At risk, natural hazards, people's vulnerability and disasters. Routledge.

Yiftachel, O., 1998. Planning and social control: exploring the "dark side". Journal of Planning Literature 12 (2), 395-406. https://doi.org/10.1177/ 088541229801200401.

Zeiderman, A., 2012. On shaky ground: the making of risk in Bogota. Environment and Planning A: Economy and Space 44 (7), 1570-1588. https://doi.org/10.1068/ a44283. 